\title{
ArcheoSciences
}

Revue d'archéométrie

33 (suppl.) | 2009

Mémoire du sol, espace des hommes

\section{Córdoba - Qurtuba - Corduba: More than two millennia of construction activity. Geophysical prospection examples from 2004 to 2008}

\section{Cornelius Meyer}

\section{OpenEdition}

\section{Journals}

Electronic version

URL: https://journals.openedition.org/archeosciences/1608

DOI: 10.4000/archeosciences. 1608

ISBN: 978-2-7535-1599-4

ISSN: $2104-3728$

Publisher

Presses universitaires de Rennes

\section{Printed version}

Date of publication: 30 October 2009

Number of pages: 221-224

ISBN: 978-2-7535-0943-6

ISSN: $1960-1360$

\section{Electronic reference}

Cornelius Meyer, "Córdoba - Qurtuba - Corduba: More than two millennia of construction activity. Geophysical prospection examples from 2004 to 2008", ArcheoSciences [Online], 33 (suppl.) | 2009, Online since 30 October 2011, connection on 01 February 2022. URL: http://journals.openedition.org/ archeosciences/1608; DOI: https://doi.org/10.4000/archeosciences.1608 


\title{
Córdoba - Qurtuba - Corduba: More than two millennia of construction activity Geophysical prospection examples from 2004 to 2008
}

\author{
Cornelius MeYer*
}

Key words: Urban archaeology, Roman, Arabic, Geomagnetics, GPR.

The Andalusian city of Cordoba (Spain) has experienced several peaks during its history of more than 2000 years. In the 3 rd century AD it became the capital, called Corduba, of the Roman province of Hispania Ulterior Baetica. It played a role of importance again in the Byzantine and Visigoth Empires. In the 8th century it reached its apogee as Qurtuba, the capital of the Umayyad Caliphate. Declining from the beginning of 11th century when the Caliphate collapsed, it did not recover until after the Reconquista under Ferdinand III of Castile in 1236. The most recent boom began after the end of Franco's regime in 1975 . This by then underdeveloped peripheral region of Andalusia benefited from industrial development in the end of the 1970s and from the controversial building boom of the 1980s in southern Spain.

It is common knowledge that intensive building activities may seriously damage archaeological monuments. Especially in places like Cordoba, where the perimeter of the Umayyad capital of the 10th century was much bigger than the present-day city, virtually every construction site strikes archaeological remains. To avoid loss of a rich architectural and archaeological heritage, Cordoba's city council has established the Oficina de Arqueologia under the direction of archaeologist Juan F. Murillo. This institution runs its own excavations as well as contracting companies for such work and for archaeogeophysical prospection projects.

Between 2004 and 2008 Eastern Atlas was contracted repeatedly to carry out geophysical prospection surveys as part of planning approval procedures for big construction projects. Geomagnetic mapping and GPR prospection were applied. The total investigated area covers 58 hectares. The main challenge lay in the location of the investigated areas in urban wasteland, close to industrial areas and partly serving as a refuge for socially marginalized groups. These terms implicated varying near-surface contamination making geophysical investigations more difficult.

The practicability of the most applied methods in archaeogeophysics was evaluated. Geomagnetic prospection turned out to be a very useful tool for localizing Roman settlement remains as well as Arabic structures in the perimeter of the Cordoba Metropolitan Area. GPR investigations proved to be more difficult. The main reason for the lack of reliably good results in GPR prospection is the geological environment of Cordoba. The city is situated in the alluvial deposits of the Guadalquivir river, mainly characterized by clayey alfisols. Furthermore, the structure of the Arabic settlements (arrabales) is very het-

\footnotetext{
* eastern atlas Geophysical Prospection. (cornelius@eastern-atlas.com)
} 
erogeneous, i.e., the walls and floors are made of different kinds of construction materials: mud brick, baked brick and boulder stones, complicating the interpretation of GPR data. The presented examples from the PP-O1 area and the Avenida de la Victoria prove the poor penetration and resolution of GPR measurements in Cordoba.

However, very impressive results were obtained by means of geomagnetic mapping, using multi-channel fluxgate arrays (Fig. 1). The data from the PP-O7 area show ground-plans of complete quarters of the western arrabales of Cordoba (Fig. 2), meanwhile in the PP-O1 area, an Arabic rural villa, almunia, was located. On the eastern outskirts of the town, in area PP-LE1, several Roman structures (Fig. 3) were detected although the area had been seriously contaminated by illegal waste dumping.

The obtained results show that geophysical prospection can be a powerful tool in the archaeological investigation of areas even in highly contaminated suburban zones. Methods need to be chosen considering area geology, the type and character of archaeological structures to be found and the environmental conditions.

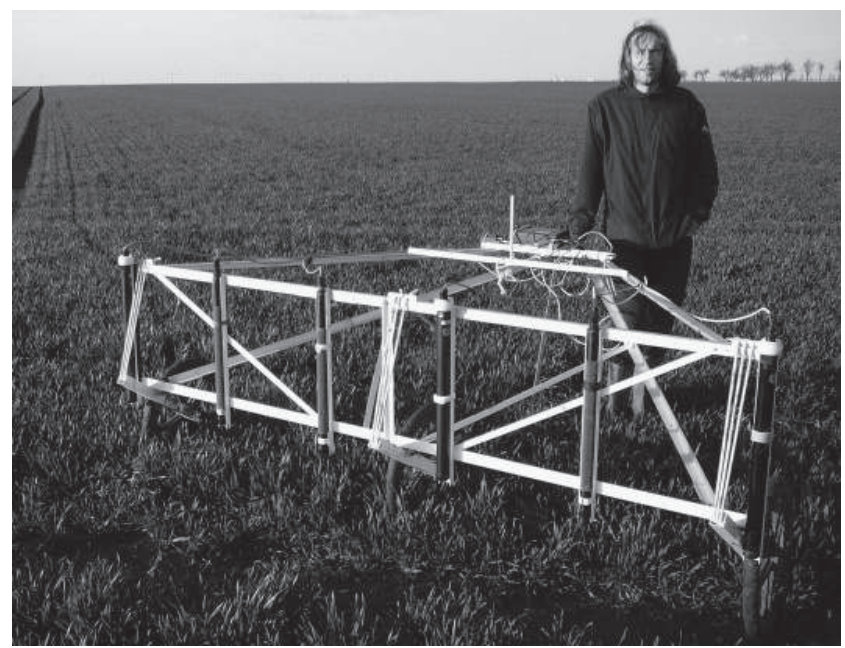

Figure 1: Six-channel fluxgate array on ultra-light cart. 


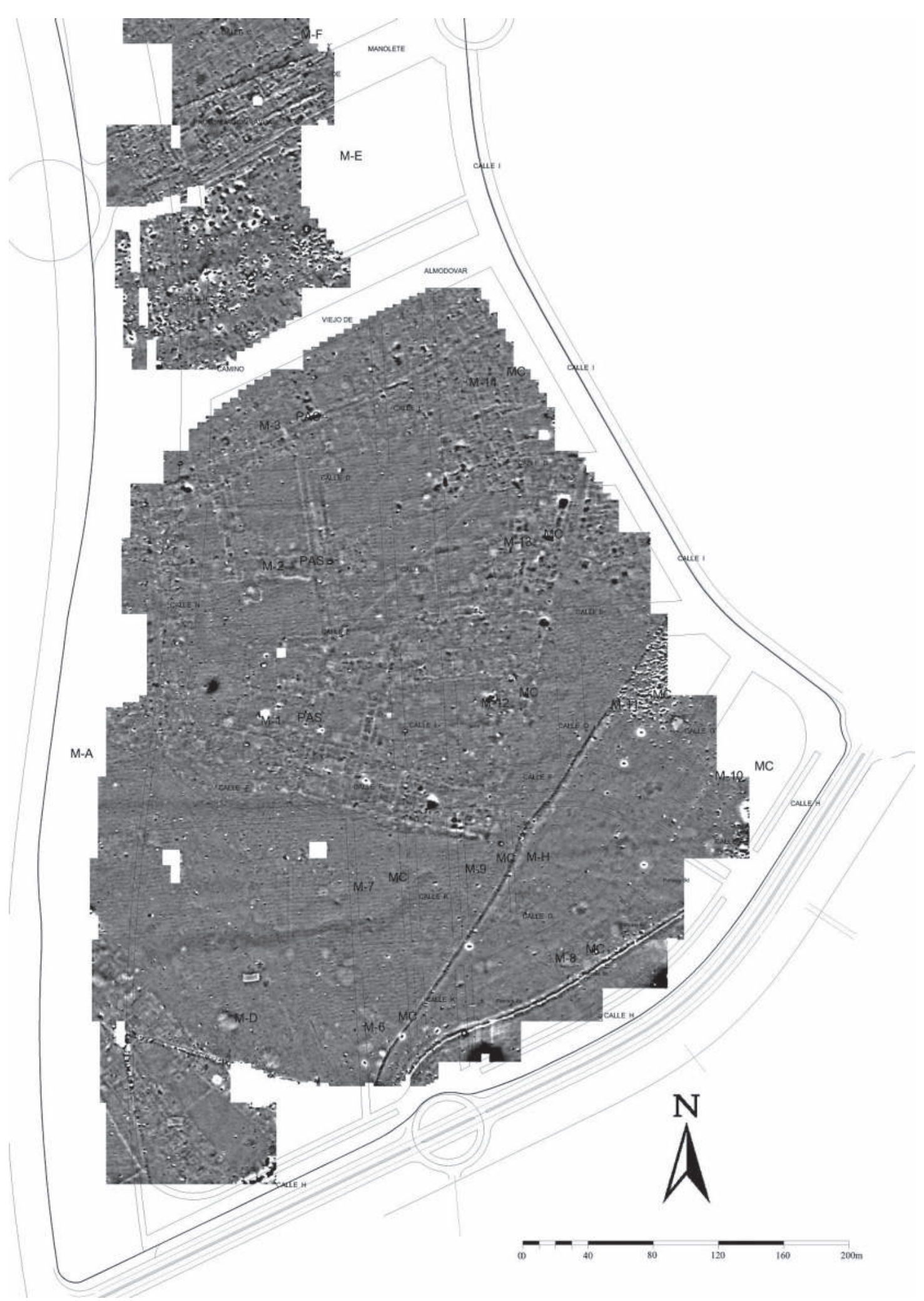

Figure 2: Arrabales in Cordoba. Geomagnetic map of PP-O7 area. Dynamics: \pm 15 nT/m. 


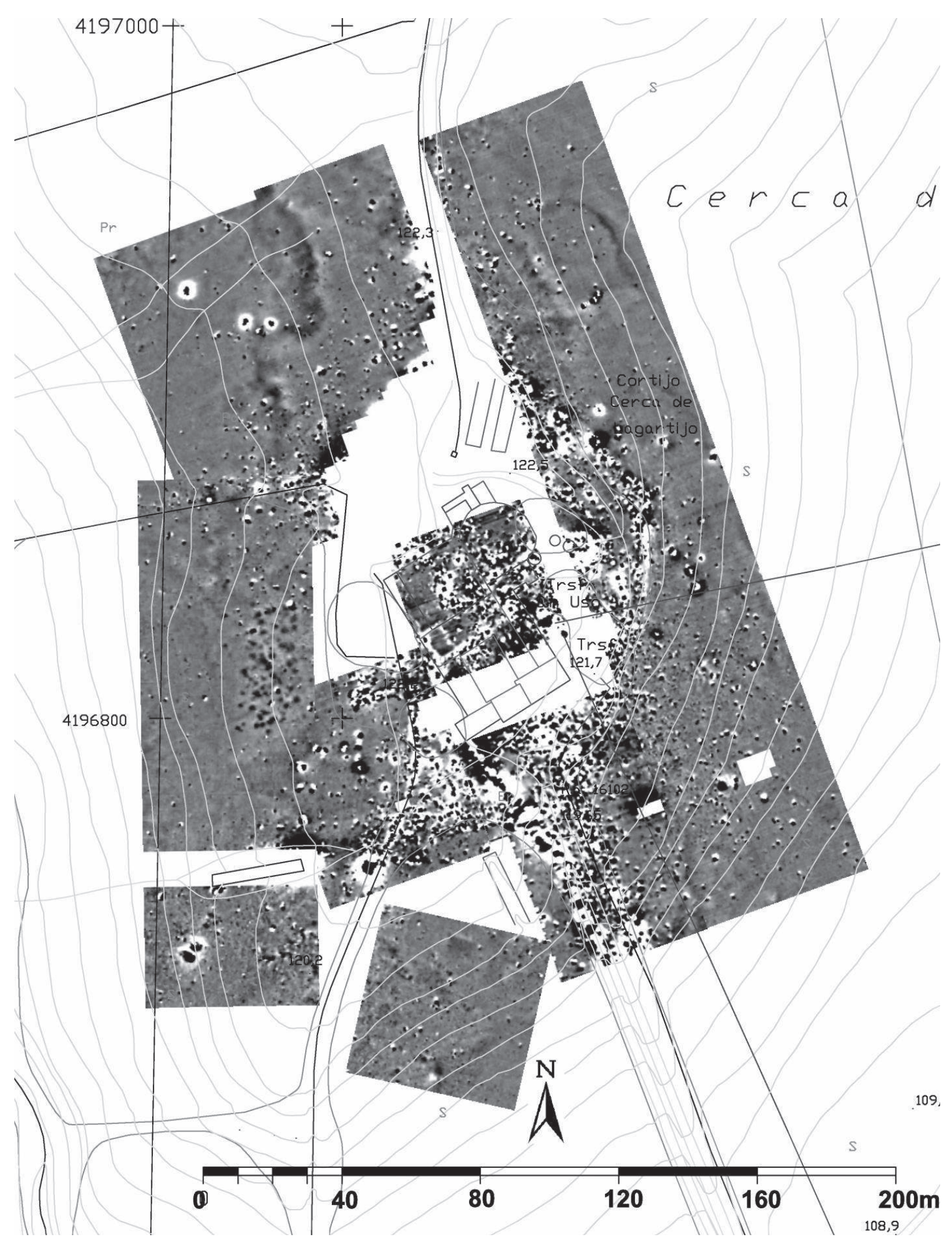

Figure 3: Roman settlement and illegal waste dump. Geomagnetic map of the Cortijo de Lagartijo area (PP-LE1). Dynamics: $\pm 15 \mathrm{nT} / \mathrm{m}$. 